\title{
Angiogenic potency evaluation of cell therapy candidates by a novel application of the in vitro aortic ring assay
}

Farwah Iqbal $1^{1,3^{*}}$, Peter Szaraz ${ }^{1,3^{*}}$, Matthew Librach ${ }^{1}$, Andrée Gauthier-Fisher ${ }^{1}$ and Clifford L. Librach ${ }^{1,2,3,4}$

\begin{abstract}
Background: Due to limitations of current angiogenesis assays, we aimed to develop a novel application of the rat aortic ring assay to assess the angiogenic potential of mesenchymal stromal cells (MSCs). First-trimester human umbilical cord-derived perivascular cells (FTM HUCPVCS) have multipotent characteristics and previously demonstrated angiogenic potential. We compared the effect of this young source of MSCs and adult bone marrow stromal cells (BMSCs) on ex vivo aortic endothelial network formation.

Methods: Thoracic segments of adult rat aortas were isolated, sectioned and embedded into Matrige $\mathrm{I}^{\mathrm{TM}}$. Fluorophore-labeled FTM HUCPVC lines and BMSCs $(N=3)$ were cocultured with developing endothelial networks (day 0). MSC integration, tube formation and endothelial network growth were monitored daily using phase-contrast and fluorescence microscopy. Quantification of endothelial networks was performed using ImageJ network analysis software on day 5 of coculture.
\end{abstract}

Results: FTM HUCPVCs from two umbilical cord samples migrated toward and integrated with developing aortic ring tubular networks while displaying elongated morphologies (day 1). In contrast, BMSCs did not show targeted migration and maintained spherical morphologies with limited physical interactions. Within 1 week of coculture, FTM HUCPVC lines contributed to significantly greater radial network growth and network loop formation when compared to BMSCs and untreated networks.

Conclusions: We have developed a novel potency assay to assess the angiogenic potential of cell therapy candidates. Favorable properties of FTM HUCPVCS over BMSCs that we observed with this assay and which merit further study include chemotaxis, affinity for developing vasculature, and physical supportive interactions contributing to the development of endothelial networks.

Keywords: Angiogenesis, Aortic ring assay, Cell migration, Cellular regenerative therapy, Endothelial networks, Mesenchymal stromal cells, Perivascular cells, Umbilical cord

\section{Background}

Development of new blood vessels is an essential process required for the regeneration of tissue injured by pathological processes including ischemia, inflammation, degeneration and traumatic injury $[1,2]$. Development of new therapies to achieve functional tissue regeneration must therefore involve re-establishment and maintenance of healthy blood flow. Several interconnected

\footnotetext{
*Correspondence: farwah.iqbal@mail.utoronto.ca; peter@createivf.com ${ }^{1}$ The Create Fertility Centre, 790 Bay Street, Suite 412, Toronto, Ontario M5G $1 \mathrm{~N} 8$, Canada

Full list of author information is available at the end of the article
}

cellular and molecular mechanisms regulate the three major processes involved in re-establishment of functional circulation for effective tissue regeneration: vasculogenesis, angiogenesis and arteriogenesis [3, 4]. Induction of angiogenesis by delivering therapeutic factors in the form of proteins or genetic materials has been studied extensively and reached clinical trials [5-7]. A significant challenge in this regard has been achieving the efficient delivery of factors such as vascular endothelial growth factor (VEGF), platelet-derived growth factor (PDGF) and/or basal fibroblast growth factor (bFGF) to sites of injury. Consequently, results observed in clinical practice were 
inconsistent between published studies $[8,9]$. This variability may be attributed to the limited longevity of nucleic acid constructs and polypeptides at the target site and finite targets of growth factors, resulting in only transient effects $[10,11]$. Thus, for successful regeneration, there is a need for multitargeted approaches with sustained activity. This need to address multiple aspects of vascular formation over a longer period of time explains the shift from growth factor delivery to stem cell-based therapies. Stem cells may have the potential to locally produce angiogenic factors, self-replicate and/or directly differentiate into new blood vessels $[12,13]$. Therefore, supplying potential angiogenic supporting cell types with all, or some, of these properties into ischemic tissue holds great promise. The delivery of "adult" stem or progenitor cells has mainly focused on endothelial progenitor cells (EPCs) and mesenchymal stromal cells (MSCs) [14-17].

The lack of a "gold standard" in vitro assay is one of the challenging aspects of studying angiogenesis and evaluating the efficacy of potential new drugs and candidate cell types. An ideal angiogenesis assay must be robust, rapid, reproducible and reliable. It must include assessment of multiple parameters, include positive and negative controls, and most importantly mirror expected preclinical and clinical observations [18]. Although a significant number of in vitro and in vivo assays are available (Table 1) [18-38], they each have various limitations in terms of applicability and feasibility. In general, most in vitro assays evaluate the effects of cells or compounds on endothelial cell migration, proliferation and differentiation into tubular structures, all of which are important for angiogenesis. However, 'translatable' assays should also evaluate: efficiency to promote the formation of functional blood vessels; augmentation or replacement of supporting cell types, such as pericytes, smooth muscle cells and fibroblasts, in addition to endothelial cells; and processing of extracellular matrix (ECM) and/or basement membrane. Despite efforts to coculture various vascular cell types together, there has been little success in developing an assay that includes all of the aforementioned. In vivo assays allow the direct implantation of test products into animal models, allowing qualitative and quantitative analysis of angiogenic responses. Limitations of in vivo approaches include animal species restrictions, xeno-immune rejection, complex setup protocols, cost and technical quantification methods [2, 39].

Due to the shortage of available angiogenesis assays, we propose a modified application of the previously described aortic ring assay [40]. The aortic ring assay was first reported in 1990 by Nicosia and Ottinetti [41] as a unique ex vivo angiogenesis assay, having clear advantages over other in vitro assays. Advantages of this assay include: easy to observe tubular structures; accessory supportive cells (smooth muscle cells, fibroblasts and pericytes); ECM from host and/or supplied (fibrin); endothelial cells not preselected by passaging and therefore are in a nonproliferative state; lack of inflammatory components; and quick and inexpensive set up [42-44]. Typically, the aortic ring assay is used to test the angiogenic potential of small secretory proteins $[45,46]$ and pharmacological agents $[47,48]$, and evaluate angiogenic responses of transgenic mouse models following genetic alteration of key angiogenic factors $[49,50]$. Earlier research articles focused on the contribution of aortic tissue resident nonendothelial cell types to the angiogenic response, such as resident macrophages and mural smooth muscle cells, or evaluated the reaction of tumor aggregates with the aortic ring-derived endothelial networks [43]. We present a novel approach to study the angiogenic effect of potential candidates for regenerative cell therapy (Fig. 1). Compared to the article by Nicosia and Ottinetti [41], we present a method to study homing, integration and network developing properties of therapeutic candidate cell types, with the addition of performing downstream analysis including immunophenotyping and gene expression profiling of both endothelial cells and administered human cells (Table 2).

MSCs have received significant attention in the field of cell-based regenerative medicine and cancer treatment due to their multifaceted regenerative properties, including the modulation of angiogenic processes [51-54]. While MSCs can be isolated from virtually any vascularized tissue in the body, bone marrow-derived mesenchymal stromal cells (BMSCs) are the most studied candidate for both autologous and allogeneic cell therapy [55]. BMSCs regulate hematopoietic stem cell (HSC) proliferation and differentiation, contribute to blood vessel formation and improve tissue function, particularly in the cardiac muscle [56-59]. Despite clear advantages of autologous stem cell therapy, BMSC therapy is limited by cell senescence-mediated reduction in differentiation potential and time constraints in collection and propagation protocols $[60,61]$. Importantly, many studies have demonstrated an age-associated decline in the number and function of host-derived stem cells, limiting the effectiveness of autologous stem cell therapy in aged patients $[62,63]$. The use of nonautologous cells from younger sources for transplantation, especially in older recipients, may overcome these challenges. Our group is currently investigating human umbilical cord perivascular cells (HUCPVCs) derived from the perivascular region of the human umbilical cord (HUC). These cells represent an accessible and rich source of young MSC populations with pericyte-like properties, and have been characterized from both first-trimester (FTM) and term umbilical cords [64-67]. FTM HUCPVCs have increased 
Table 1 Available assays to evaluate angiogenic potential

\begin{tabular}{|c|c|c|}
\hline Assay & References & Advantages \\
\hline \multicolumn{3}{|l|}{ In vitro } \\
\hline Endothelial proliferation assays & $\begin{array}{l}\text { Gomez and Reich } 2003 \text { [19] } \\
\text { Yu et al. } 2004 \text { [20] }\end{array}$ & $\begin{array}{l}\text { - Reproducible and easy to set up } \\
\text { - Provide quantifiable data } \\
\text { - Measure proliferation and apoptosis }\end{array}$ \\
\hline $\begin{array}{l}\text { Endothelial cell migration assays } \\
\text { - Transwell systems } \\
\text { - Wound healing assays }\end{array}$ & $\begin{array}{l}\text { Wong and Gotlieb } 1984 \text { [21] } \\
\text { Schor et al. } 2001 \text { [22] } \\
\text { Albini et al. } 2004 \text { [23] }\end{array}$ & $\begin{array}{l}\text { - Reproducible } \\
\text { - Short duration (4-6 hours) } \\
\text { - Quantitative analysis of endothelial cell } \\
\text { migration over time } \\
\text { - Sensitive to small alterations in } \\
\text { concentration gradients }\end{array}$ \\
\hline
\end{tabular}

Endothelial tube formation assays

Ex vivo

Chick aortic arch model

In vivo

Chick chorioallantoic membrane assay

Matrigel ${ }^{T M}$ plug assay

Sponge/matrix implant assay

Corneal assay

Dorsal air sac model

Zebrafish assay
Lawley and Kubota 1989 [24]

Kanzawa et al. 1993 [25]

Auerbach et al. 2003 [26]

Ribbati et al. 1995 [27]
Ejaz et al. 2004 [28]

- Useful to test angiogenic and

anti-angiogenic effects of compounds

- More representative of in vivo

angiogenesis than 2D assays

- Introduce ECM to culture system

- Measure proliferation and differentiation

- System includes nonendothelial cells (pericytes, smooth muscle cells) and ECM

- Easy set up, early cell outgrowth

(48 hours)

- Embryonic endothelial cells resemble microvascular phenotype

- Simple and inexpensive

- Ideal to implant tissue or organ grafts

- CAM membrane is immunoprivileged enabling xeno-graft studies

- Ideal for large-scale screening

- Noninvasive observation

- Quantitative histological analysis

- Matrige ${ }^{\mathrm{TM}}$ provides natural environment for angiogenesis

- Include defined polymers to study angiogenesis

- Angiogenic response can be monitored over time in live animals

- Ideal for studying tumor-induced angiogenesis

Gimbrone et al. 1974 [33] Muthukkaruppan and Auerbach 1979 [34]

Selye 1953 [35]

Oikawa et al. 1997 [36]

Rubinstein 2003 [37] Isogai et al. 2001 [38]
- New blood vessels easily observed due to the absence of background blood vessels

- Executed in mice, rats, rabbits

- Noninvasive monitoring and data easily quantifiable

- Adaptable to various applications

- Allow continuous non invasive monitoring of endothelial networks

- Enables large-scale projects

- Shared angiogenic genes and

mechanisms

- Easily monitored/quantified

- Ideal for testing of anti-angiogenic

compounds

- Suitable for genetic studies of

angiogenesis
Limitations

- Short window of analysis after culture due to endothelial cell senescence

Sensitive to cell density

- Involve endothelial cells from macrovascular origin (HUVEC)

- Difficult to define and maintain transmembrane gradients

- Inability to observe cell migration in transwell

- Challenging to establish matching conditions between control and experimental groups

- Difficult to obtain accurate results with low cell counts

- Lack of consistent lumen formation

- Homogeneous tubules

- Sensitive to uneven matrix coating of wells and cell density

- Time-consuming analysis (multiple parameters of analysis)

- Endothelial cells are in a proliferative state in the embryo (not representative of true in vivo scenarios)

- CAM has endogenous vasculature difficult to distinguish pre-existing and newly formed vasculature

- 11-day incubation time prior to

implantation of test reagents

- Incision in shell may induce inflammation and a specific angiogenic response

- Sensitive to oxygen tension

- Time consuming, including 2 weeks of plug incubation in host, isolation, sectioning, analysis

- Costly

- Implants can become encapsulated with cytokine-secreting macrophages

- Inflammatory response may interfere

with angiogenic response

- Undesirable fibrosis

- Variable retention of test compounds in different substrates

- Challenging surgical procedure

- Limited space of test substance injection

- Inflammation difficult to avoid

- Atypical angiogenesis because cornea is avascular

- Costly

- Difficult to distinguish pre-existing and newly formed vasculature

- Delicate procedure (irritation to dorsal skin)

- Relevance of fish endothelial cell angiogenesis is under debate

- Nonmammalian cell types and involves embryonic cells

- Costly to maintain breeding conditions 


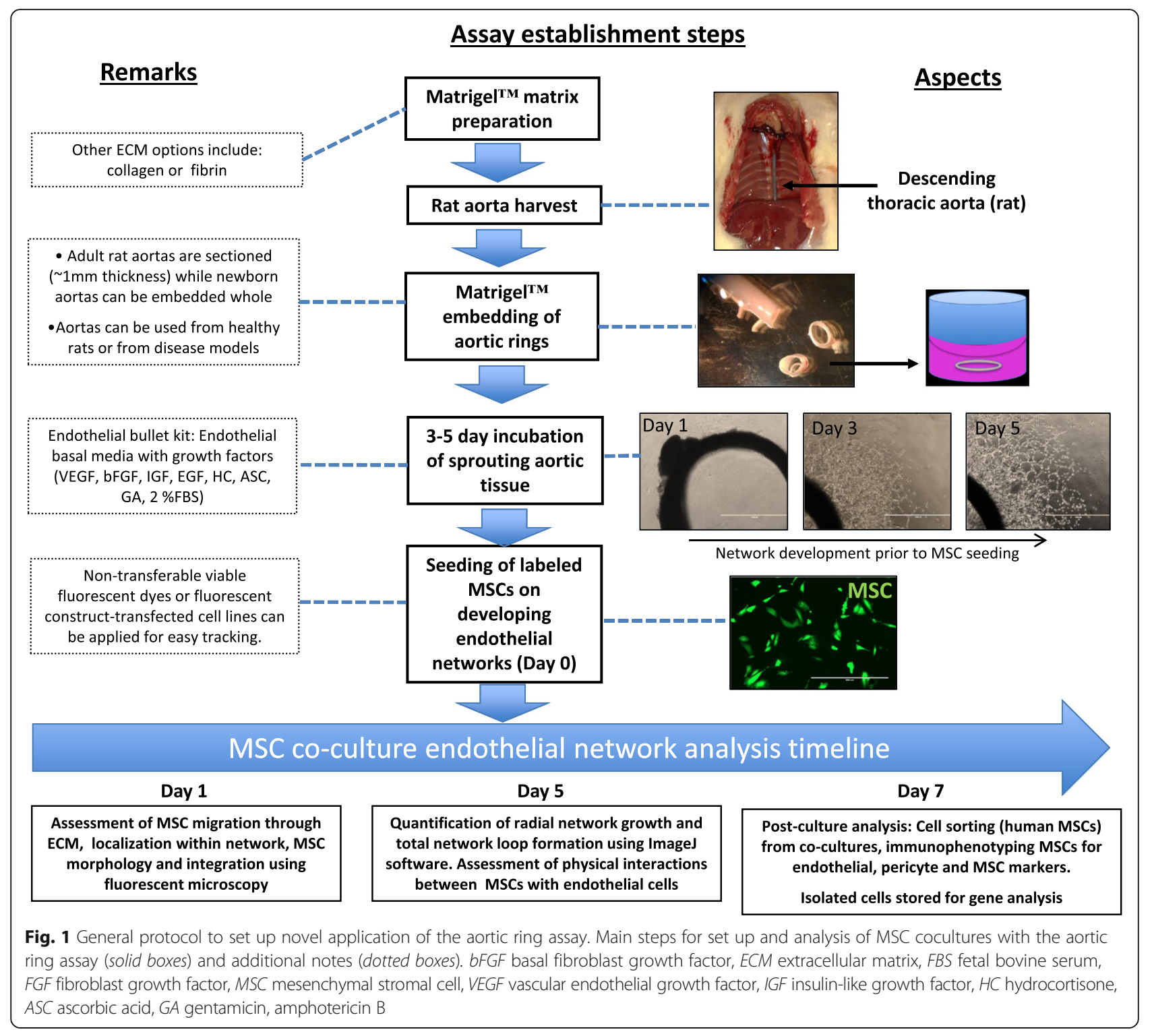

expansion potential, as well as immunoprivileged and multipotent properties [66], and preliminary experiments suggest that HUCPVCs promote significant cardiac regeneration and improve cardiac function following myocardial infarction when compared to BMSCs [68].

Here we present a novel application of the aortic ring assay to assess the ability and potency of cellular therapy candidates to mediate ECM processing, migrate to areas of angiogenesis and contribute to vessel development through physical contact. As model cell types, we aimed to compare ontogenetically early (prenatal) and late (adult) sources of human MSCs, human FTM HUCPVCs and human BMSCs in the aortic ring assay.

\section{Methods}

\section{Use of animals}

All animal procedures were conducted and reported according to ARRIVE guidelines and approved by the Animal Care Committee of the University Health Network (Toronto, Canada). All studies were performed with institutional research ethics board approval (AUP 3220.5, University of Toronto, Toronto, Canada). Aortic tissues were isolated from Sprague-Dawley female rats of reproductive age. Animals were euthanized in carbon dioxide chambers set to $20 \%$ gas replacement (flow rate $=$ chamber volume $\times 0.2$ per minute). The aorta was exposed by an excision through the chest cavity and removal of lung tissue. The aorta was identifiable adjacent to the vertebral column and white in color. Using surgical tools, the 
Table 2 Comparison of aortic ring assay applications and novelty

\begin{tabular}{|c|c|c|}
\hline & Nicosia and Ottinetti 1990 [41] & Present study 2017 \\
\hline Application/novelty & $\begin{array}{l}\text { - Developed a quantitative and reproducible angiogenesis } \\
\text { assay for cell-free compounds } \\
\text { - Tested the effect of inhibitory/stimulatory soluble factors } \\
\text { on angiogenesis }\end{array}$ & $\begin{array}{l}\text { - Modified a quantitative and reproducible angiogenesis } \\
\text { assay for coculturing cells } \\
\text { - A novel application to study the angiogenic function and } \\
\text { potency of cell therapy candidates for clinical application } \\
\text { and banking }\end{array}$ \\
\hline Set up & $\begin{array}{l}\text { - Thoracic rat aorta embedded in fibrin or collagen } \\
\text { - Prepared agarose wells to support aortic rings } \\
\text { - Endothelial media: MCDB } 131 \text { to a mixture of 1:1 with } \\
\text { DMEM F12 (FBS-free) } \\
\text { - Stimulation of angiogenesis with mouse sarcoma } 180 \\
\text { - Studied inhibition of angiogenesis using hydrocortisone }\end{array}$ & $\begin{array}{l}\text { - Thoracic rat aorta embedded between two layers of } \\
\text { Matrigel } \\
\text { - Support of angiogenesis from EHS mouse sarcoma extract } \\
\text { (Matrigel }\left.\right|^{\mathrm{TM})} \\
\text { - Endothelial basal media supplemented with } 2 \% \mathrm{FBS} \text { and } \\
1 \% \text { penicillin/streptomycin for cocultures } \\
\text { - Prelabeled MSCs cocultured with developing endothelial } \\
\text { networks for tracing }\end{array}$ \\
\hline Analysis & $\begin{array}{l}\text { - Daily counting of newly developed microvessels (15 days) } \\
\text { using bright-field microscopy } \\
\text { - Florescent imaging of endothelial networks using FVIII-Ra } \\
\text { immunohistochemistry }\end{array}$ & $\begin{array}{l}\text { - Quantified radial network growth and network loops at } \\
\text { day } 5 \text { following MSC coculture } \\
\text { - Live-cell florescence imaging of MSC migration, } \\
\text { integration site preference and morphology (coverage) in } \\
\text { endothelial networks } \\
\text { - Developed methods to extract MSCs and endothelial cells } \\
\text { to perform downstream analysis including flow cytometry } \\
\text { and GPCR }\end{array}$ \\
\hline
\end{tabular}

FBS fetal bovine serum, MSC mesenchymal stromal cell

thoracic aorta was excised and sectioned into $\sim 1 \mathrm{~mm}$ sections yielding approximately 15-20 rings. To account for variability between animals, each experiment was repeated three times $(N=3)$.

\section{Use of matrix}

Matrigel $^{\mathrm{ma}}$ (Corning) was selected for the assay due to the basement membrane-like composition [69]. Matrigel ${ }^{\mathrm{m}}$ $(200 \mu \mathrm{l})$ was coated evenly on 12-well plates (on ice) and then placed in a humidified incubator $\left(37^{\circ} \mathrm{C}, 5 \% \mathrm{CO}_{2}\right)$ for 30 minutes. Once Matrigel ${ }^{\mathrm{Tm}}$ was polymerized; a freshly obtained aortic ring was placed at the center of each well. Then $300 \mu \mathrm{l}$ of Matrigel $^{\mathrm{Tm}}$ was carefully applied on top of the aortic ring tissue and incubated for 30 minutes $\left(37^{\circ} \mathrm{C}\right.$, $5 \% \mathrm{CO}_{2}$ ). Once polymerized, $1000 \mu \mathrm{l}$ of prewarmed endothelial growth media (EGM) (see next section) was added to each well and then placed back into the incubator and intermittently observed until endogenous endothelial networks developed (3-5 days).

\section{Use of media}

Following the final Matrigel ${ }^{\mathrm{Ts}}$ polymerization, the aortic ring sandwich assay was incubated in $1000 \mu \mathrm{l}$ of Endothelial Growth Media-2 (EGM-2 $2^{\mathrm{rm}}$ ) BulletKit ${ }^{\mathrm{tm}}$ (Lonza catalog no. CC-3162). EGM-2 was removed 24 hours following incubation and replaced with $1000 \mu \mathrm{l}$ of endothelial basal media (EBM) supplemented with $2 \%$ fetal bovine serum (FBS) (Hyclone) and 1\% penicillin/streptomycin (P/S) (Gibco) for the remainder of the assay and replaced every 2 days.

\section{Cell culture of FTM HUCPVCs and BMSCs}

FTM HUCPVCs (8-9 weeks of gestation) were isolated as described previously [66]. FTM HUCPVCs were expanded in StemPro ${ }^{\circ}$ MSC SFB XenoFree culture media supplemented with $1 \%$ StemPro $^{\circ}$ SFM XenoFree Supplement, $1 \%$ L-glutamine and $1 \% \mathrm{P} / \mathrm{S}$. Prior to culture, $10-\mathrm{cm}^{2}$ culture dishes (Corning) were coated with $7 \mathrm{ml}$ of PBS containing $\mathrm{Ca}^{2+}, \mathrm{Mg}^{2+}$ and $1 \%$ of CELLstart ${ }^{\mathrm{mm}}$ humanized substrate for stem cell culture (Thermo Fisher Scientific) and placed in the incubator for 1 hour at $37{ }^{\circ} \mathrm{C}, 5 \% \mathrm{CO}_{2}$. For the assay, passage 3 (P3) of two FTM HUCPVC lines (FTM 1 and FTM 2, two donors) were thawed and plated at a density of $2.5 \times 10^{3}$ cells $/ \mathrm{cm}^{2}$ in a $10-\mathrm{cm}^{2}$ culture dish and incubated at $37{ }^{\circ} \mathrm{C}, 5 \% \mathrm{CO}_{2}$. FTM HUCPVCs were passaged at 70 $80 \%$ confluency and cocultured with aortic ring assay at $\mathrm{P} 4$. The BMSC line were purchased commercially (Lonza) and expanded in Minimum Essential Medium Eagle with alpha modifications ( $\alpha$-MEM), 10\% FBS and 1\% P/S. BMSCs were cultured at a density of $5.0 \times 10^{3}$ cells $/ \mathrm{cm}^{2}$ in $10-\mathrm{cm}^{2}$ culture dishes. BMSCs were passaged at $70-80 \%$ confluency (P4) and cocultured with the aortic ring assay at P4 (one donor).

\section{Coculture set up}

For coculture, MSCs were harvested and prepared as single-cell suspensions using TrypLE (Invitrogen) at $37{ }^{\circ} \mathrm{C}$ for 5 minutes. MSCs were prestained with cell tracker green dye (CTG) (CellTrackerGreen ${ }^{\mathrm{Tw}}$; LifeTechnologies) for 30 minutes, washed and resuspended in $\mathrm{EBM}+2 \%$ FBS, $1 \%$ P/S. Using an automated cell counter (Invitrogen), approximately 10,000 prestained MSCs were cocultured with aortic ring assay endothelial networks (day 0 ).

\section{Imaging and quantification of endothelial networks}

Following 24 hours of incubation, bright-field (Olympus) and fluorescence microscopy images (EVOS ${ }^{\mathrm{Tx}}$; LifeTechnologies) 
of aortic ring cocultures were taken to evaluate MSCmediated ECM processing and migratory potential. The preferential homing of MSCs to unstructured proliferating areas (Fig. 2a), previously developed endothelial networks (Fig. 2b) or newly developing endothelial networks was assessed (Fig. 2c). These imaging methods also documented overall network development, and physical interactions between MSCs and endothelial cells. Phase-contrast images of four fields were taken to measure radial network growth and the total number of network closed loops up to 7 days (Fig. 2). The quantification of network growth and network loop formation was quantified using program ImageJ, utilizing the angiogenesis plugin on day 5 of coculture [70].

\section{Statistical analyses}

All results were generated from three independent experiments $(N=3)$ with two rings for each treatment group $(n=2)$. Data were analyzed using Prism ${ }^{\mathrm{Tx}}$ software (GraphPad). Results were presented as mean \pm standard deviation (SD), unless otherwise indicated. Statistical significance was determined using a one-way ANOVA test. Post-hoc analysis was calculated with Tukey's test for pairwise comparison. Differences in overall network growth and loop formation following coculture were considered significant when $p \leq 0.05$.

\section{Results}

Fluorescence microscopy allows qualitative measurements of MSC migration, integration and morphology in conjunction with developing endothelial networks in the aortic ring assay

Human MSCs were prestained and cocultured with ex vivo cultured rat aortic rings in order to observe MSC migration in Matrigel ${ }^{\mathrm{Tw}}$ and homing preferences to endothelial networks (Fig. 3a-f). CTG-positive cells were imaged 24 hours following cell administration. Both FTM 1 and FTM 2 localized at the periphery of developing endothelial networks while displaying elongated cell morphologies. FTM HUCPVCs appeared to migrate to newly developing networks and contributed to the further development of endothelial networks (Fig. 3a, b, d, e). Alternatively, BMSCs demonstrated minimal site preference and homed to areas with limited endothelial tube formation and sites with significant cellular proliferation (Fig. 3c). High-magnification images of BMSCs in coculture displayed spherical morphologies when compared to FTM HUCPVC cocultures (Fig. 3f).

Following 72 hours of MSC administration, highmagnification fluorescent images were taken to further observe cell-to-cell interactions between MSCs and endothelial cells, as well as cellular morphologies (Fig. 3g-i). Both FTM HUCPVC lines (FTM 1 and FTM 2) demonstrated extensive cell-to-cell interactions with endothelial cells (Fig. 3g, h, white arrows) while displaying

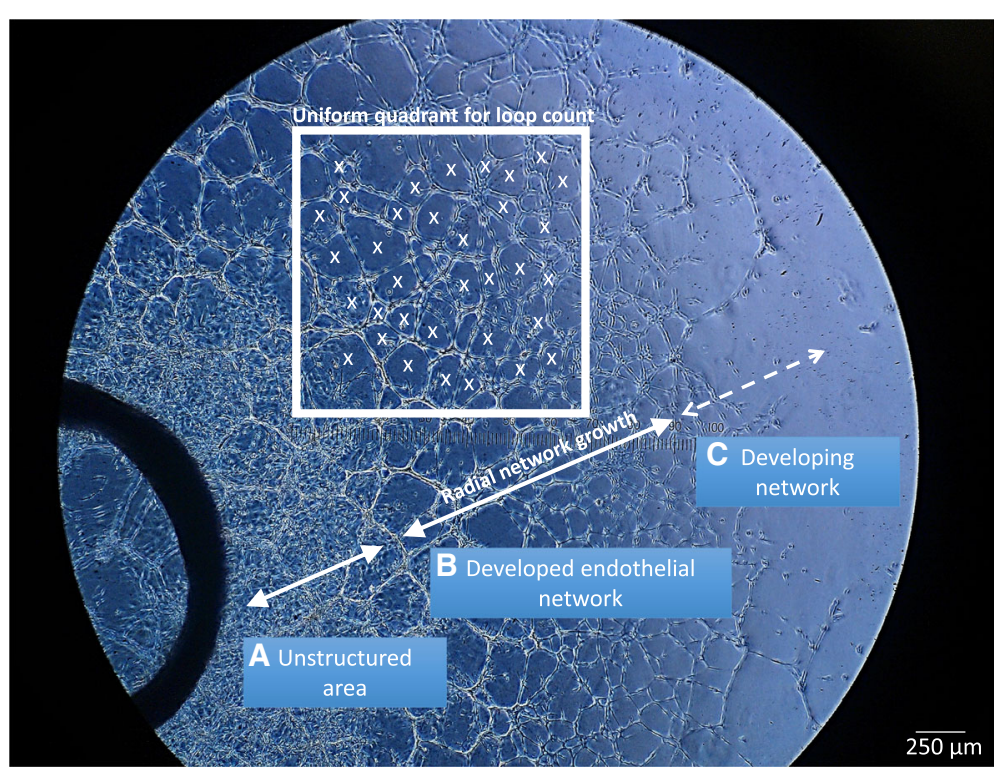

Fig. 2 Representative image of aortic ring network analysis. Endothelial networks are divided into three concentric regions based on structure: unstructured area in close proximity to aortic ring tissue (a), developed/structured endothelial networks (b) and developing networks located in the periphery of the ex vivo tissue culture $(\mathbf{c})$. Radial network growth and uniform quadrant for loop count are defined within the developed endothelial network (b). X closed endothelial loop counted in uniform quadrant. Scale bar $=250 \mu \mathrm{m}$ 


\section{$24 \mathrm{~h}$}

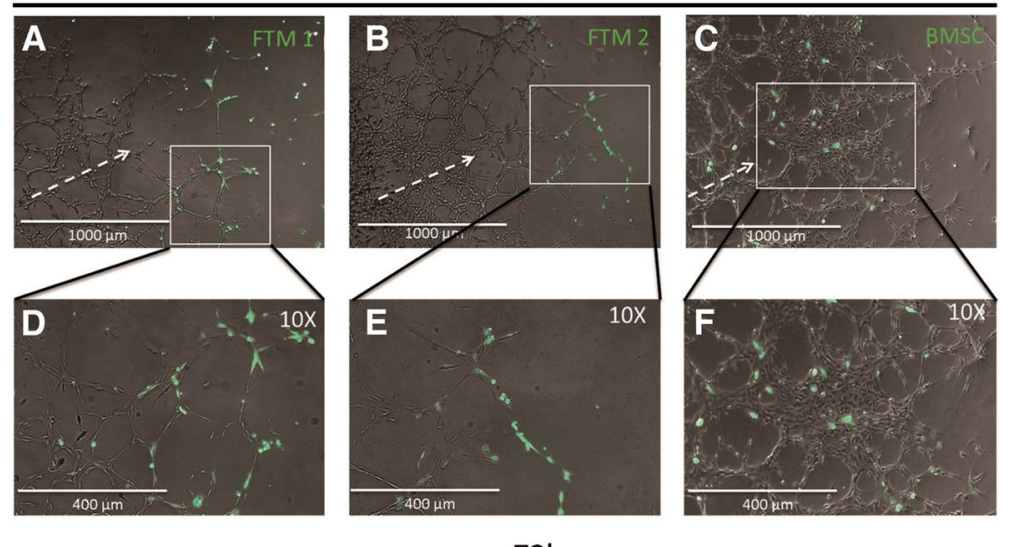

$72 \mathrm{~h}$
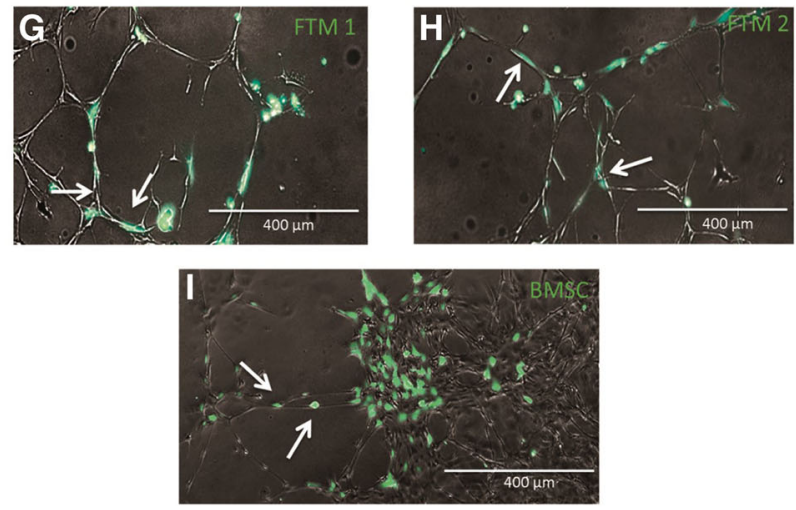

Fig. 3 Fluorescent imaging of network region-dependent integration of human MSCs in the aortic ring assay after 24 and 72 hours. Prestained (CellTrackerGreen ${ }^{\mathrm{TM}}$ ) FTM HUCPVCS and FBS containing media-expanded BMSCs added to developing aortic ring endothelial tube networks. Fluorescence microscopy images taken 24 hours after establishing MSC cocultures. FTM 1 and FTM 2 migrate through ECM and home to peripheral developing endothelial networks (a, b). Higher magnification images display elongated morphologies of FTM HUCPVCs while in close contact with endothelial networks $(\mathbf{d}, \mathbf{e})$. Fewer BMSCs process ECM and home to endothelial networks with no observable preference to peripheral developing networks (c). BMSCs display spherical cell morphologies (f). High-magnification fluorescence microscopy images of prestained MSCs in rat aortic ring assay following 72 hours of coculture (g, h, i). FTM 1 and FTM 2 display elongated morphologies while displaying endothelial coverage through direct cell-to-cell interactions with endothelial cells (solid white arrows) both in network nodes and tubules $(\mathbf{g}, \mathbf{h})$. BMSCs maintain spherical cell morphologies clustered in endothelial network nodes (i). Broken arrow shows direction of endothelial network growth from aortic ring tissue. Low-magnification images, scale bar $=1000 \mu \mathrm{m}$; high-magnification images, scale bar $=400 \mu \mathrm{m}$. BMSC bone marrow stromal cell, FTM first trimester (Color figure online)

elongated morphologies typically observed in pericyteendothelial interactions. Conversely, BMSCs were localized mainly in endothelial proliferation sites and seldom found localized within endothelial tubes or loops (Fig. 3i, white arrows). BMSCs displayed spherical morphologies, suggestive of a physically less supportive "pericyte" phenotype.

High-magnification images depict physical interactions between endothelial cells and FTM HUCPVCs in endothelial networks with prestained FTM HUCPVCs (Fig. 4a, green) adhering to unstained endothelial cells (Fig. 4a, white arrows). Alternatively, both FTM HUCPVCs (green) and endothelial cells (red) were loaded with fluorescent fluorophore prior to coculturing (Fig. 4b). Both settings revealed elongated connections between the two cell types in the network, suggesting cooperation and supportive cell behavior.

\section{Bright-field microscopy allows quantitative measurements of overall endothelial network growth when cocultured with MSC treatment groups}

Quantification of endothelial network properties was performed at day 5 of MSC cocultures. Mean network growth was calculated as the distance from proximal closed network loops closest to the aortic ring to the furthest distal closed loops (radius size) (Fig. 5a). Radial growth of endothelial tubular networks within the ECM $\left(\right.$ Matrigel $^{\mathrm{Tm}}$ ) can translate into the penetration range of newly developing vasculature in a regenerating tissue. Images were acquired and collected in a blinded manner 


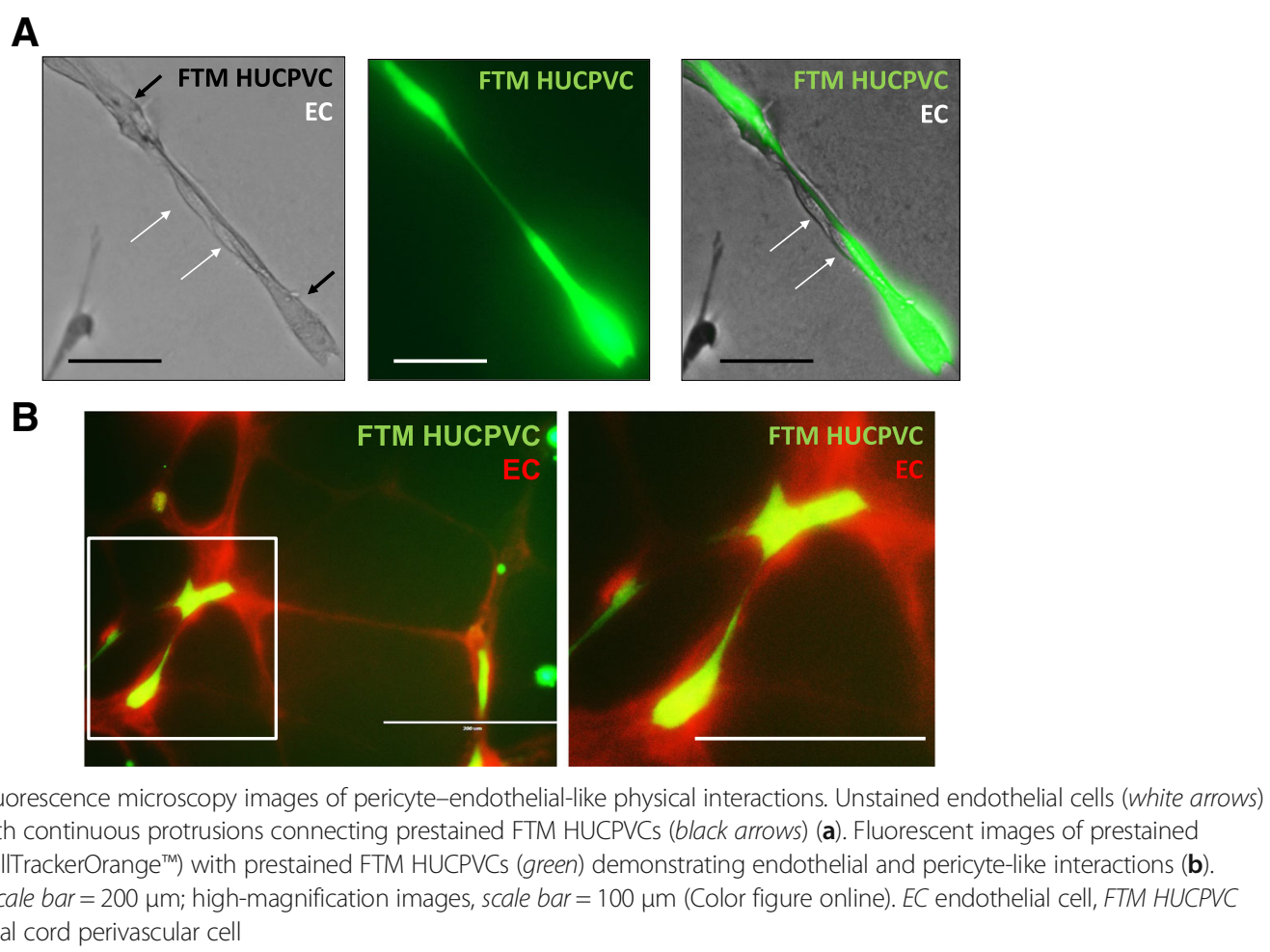

and three radius measurements were performed per image. The mean network growth of MSC-endothelial cocultures was as follows: FTM 1, $3.45 \pm 0.4 \mathrm{~mm}$; FTM 2, $3.1 \pm 0.3 \mathrm{~mm}$; and BMSCs, $1.7 \pm 0.3 \mathrm{~mm}$. Untreated endothelial networks developed a mean radius of $2.4 \pm$ $0.5 \mathrm{~mm}$. Statistical comparison between MSC treatment groups demonstrated that both FTM 1 and FTM 2 significantly increased network growth compared to BMSCs $(p \leq 0.001)$ and untreated networks $(p \leq 0.001$ and $p \leq 0.05$ respectively). Untreated endothelial networks developed significantly more than BMSCs containing cocultures $(p \leq 0.05)$. There was no significant difference in radial network growth between both FTM HUCPVC lines (Fig. 5b).

In addition to the assessment of the average growth of endothelial networks, endothelial network structure was also analyzed. Analysis of the formation of closed endothelial loops is of great importance because capillary networks consisting of more loops are able to supply a greater surface area, potentially leading to optimal tissue perfusion in vivo [71]. Uniform quadrants were defined for measurement of the complete aortic ring endothelial network. The total numbers of loops were calculated in each quadrant and averaged into one measurement of total loop formation (Fig. 5c). The average number of closed loops for FTM HUCPVC treated cocultures was $178 \pm 96$ and $134 \pm 58$ for FTM 1 and FTM 2 respectively, $23 \pm 2$ for BMSCs and $79 \pm 14$ for untreated rings. FTM 1 and FTM 2 HUCPVC treated networks contributed to greater endothelial loop formation when compared to BMSCs ( $p \leq 0.001$ and $p \leq 0.05$ respectively). The average number of closed loops of FTM-1-treated aortic ring networks was significantly greater than untreated networks $(p \leq 0.05)$.

\section{Discussion}

Cell-based therapy is currently the most extensively studied approach for therapeutic angiogenesis. Due to conflicting results reported by clinical studies, there is a lack of consensus regarding the ideal candidate cell type(s) for therapeutic neovascularization. An ideal cell candidate for vascular regeneration should home to the injury site, subsist in the regenerating environment and contribute to ECM remodeling to promote the development of microvasculature $[16,72,73]$. The exact mechanisms of how different stem or progenitor cells contribute to vessel formation are under investigation. Candidate cell types may either indirectly contribute to vascular regeneration by secreting paracrine factors, recruit host progenitor and supportive cell types, and provide physical support to developing vasculature, and/or directly differentiate into endothelial-like cells [74]. A major challenge preceding in vivo studies of angiogenesis is selection of appropriate functional assays that can accurately and efficiently evaluate the therapeutic agent in vitro. Due to limitations of available angiogenesis 
A

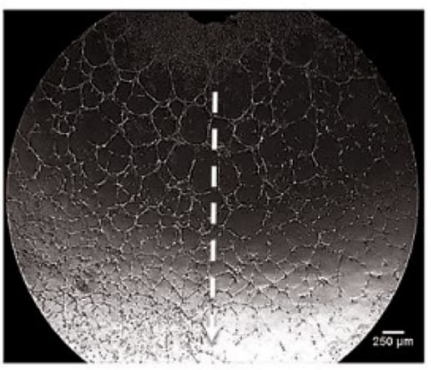

BMSC

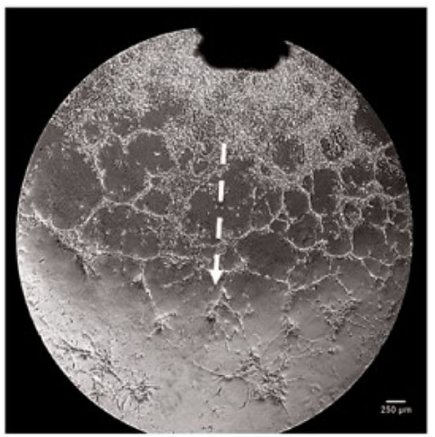

B
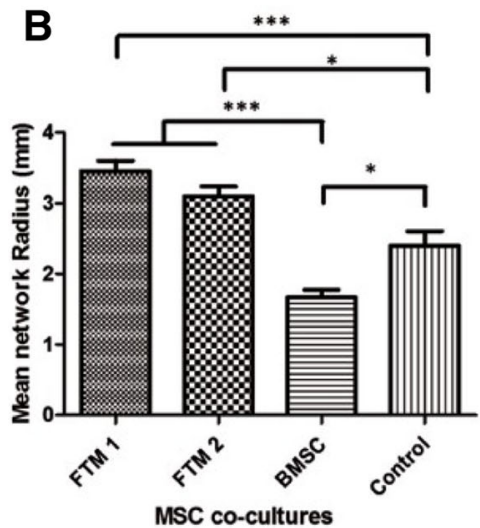

FTM 2

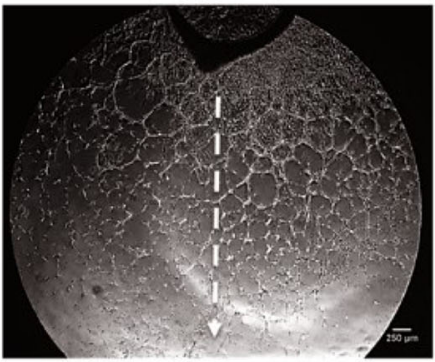

Untreated

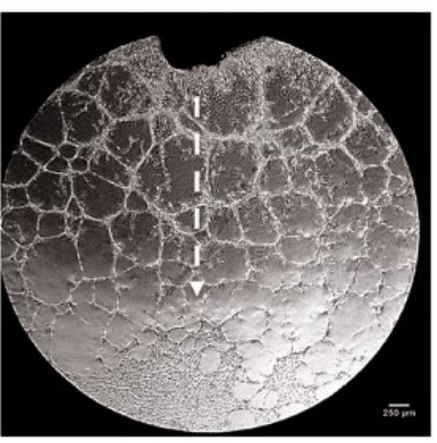

C

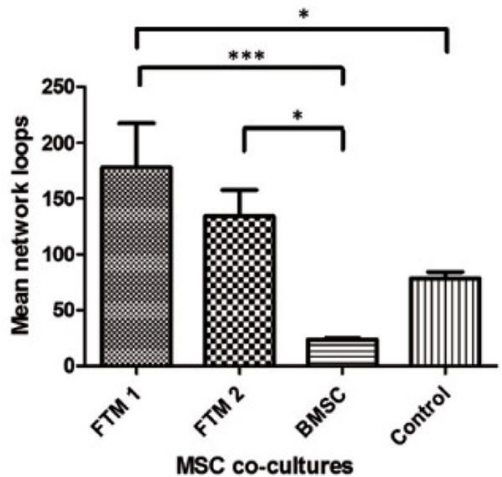

Fig. 5 Quantification of endothelial networks at day 5 of MSC coculture with the aortic ring assay. Phase-contrast microscope images of MSC treatment groups taken at day 5 following MSC coculture and utilized to quantify network properties including mean network growth and mean network loop formation (a). Both FTM HUCPVCs contributed to greater network growth when compared to BMSC cocultures ( $p \leq 0.001)$. FTM 1 and FTM 2 contributed to greater network growth when compared to untreated networks $(p \leq 0.001, p \leq 0.05$ respectively). BMSC cocultures contributed to inferior network growth when compared to untreated endothelial networks $(p \leq 0.05)(\mathbf{b})$. $p$ calculated using one-way ANOVA as $p=0.0001$ using Tukey's post test $(N=3, n=2)$. Network loops with at least four closed sides were quantified (c). Both FTM 1 and FTM 1 cocultures developed greater network loops when compared to BMSC cocultures ( $p \leq 0.001, p \leq 0.05$ respectively). There was no statistical difference between BMSCs and untreated aortic networks. FTM 1 contributed to greater closed loops when compared to untreated networks $(p \leq 0.05)$. Average of four fields of endothelial networks quantified. $p$ calculated using one-way ANOVA as $p=0.0008$ using Tukey's post test $(N=3, n=2)$. Scale bar $=250 \mu \mathrm{m}$. For pairwise comparison: ${ }^{*} p \leq 0.05,{ }^{* * *} p \leq 0.001$. BMSC bone marrow stromal cell, FTM first trimester

assays (Table 1), typically more than one assay is used when testing potential angiogenic therapies. An ideal functional assay to evaluate regenerative cell types should be robust, rapid, reproducible, quantitative and reflect the physical and cellular components that determine angiogenesis in vivo [75].

Here, we proposed a novel application of the aortic ring assay that can be utilized to study potential mechanisms involved in angiogenesis and assess the potency of cell candidates for regenerative therapy. For these studies, we compared the angiogenic potential of two independent FTM HUCPVC lines with commercially available adult BMSCs in vitro. We developed a novel method that involves coculturing MSCs with rat aortic endothelial networks to quantify net effects on endothelial network development. Following 24 hours of coculture, fluorescence microscopy demonstrated that FTM HUCPVCs home and integrate into peripheral sprouting 
endothelial networks and display significant endothelial coverage. BMSCs did not display preferential homing and displayed minimal cell-to-cell interactions with endothelial cells. Both FTM HUCPVC line cocultures contributed to greater network growth when compared to BMSC cocultures and untreated networks $(p \leq 0.05)$, and both FTM HUPCVCs lines contributed to significantly greater network loops when compared to BMSCs $(p \leq 0.05)$. Our test also suggested a difference between FTM HUCPVC lines: cocultures using FTM 1 developed significantly greater loops when compared to untreated networks. Our experiments suggest that ontogenetically young FTM HUCPVCs may have greater angiogenic potential when compared to older BMSCs and that variability between cell lines of the same tissue origin is also detectable with this method.

Angiogenesis is a multistep process typically initiated by injury or tissue remodeling, where endothelial cells degrade the basement membrane using proteases, migrate and proliferate into extracellular space [76]. Once new vessels are initiated, pericytes and smooth muscle cells stabilize and support immature vessels. These interactions between endothelial cells and mural cells are crucial for the transition of immature vasculature into mature and functional vasculature [77, 78]. FTM HUCPVCs are a young source of MSCs with pericytelike properties. Supporting endothelial cells and vasculature is the inherent function of HUCPVCs in the umbilical cord. FTM HUCPVCs express pericyte-associated markers including CD146, NG2 and PDGFR- $\beta$ [66]. These characteristics likely contributed to the positive effect we observed on endothelial network development in vitro as well as the intercellular interactions and supportive morphology of FTM HUCPVCs. CD49f is known to be a regulator of both cell-to-cell membrane adhesion $[79,80]$ and, via its laminin binding potential, cell-tobasal membrane adhesion [81]. We have shown previously that HUCPVCs have an increased expression of CD49f [82], with FTM HUCPVCs expressing the highest level of CD49f. Although BMSCs express vascular cell adhesion molecule-1 (VCAM-1), CD146, PDGF- $\beta$ and smooth muscle $\alpha$-actin [83-85], we observed minimal supportive elongated morphology, possibly explaining the significant decrease in radial network growth and network loop formation when compared to FTM HUCPVCs. Interestingly, BMSC cocultures displayed a significant reduction in network radial growth $(p \leq 0.05)$ and endothelial loop formation when compared to untreated networks. It has been shown that the regression of developing microvascular networks depends less on endothelial cell death than endothelial cell arrangement and disarrangement [86]. This can explain our observation that a cell type not contributing to the structured growth of the network causes network regression.
BMSCs did not integrate with structured or developing endothelial networks but localized with unstructured endothelial cell masses, causing decreased network development compared to untreated aortic rings. In addition to insufficient physical interactions between BMSCs and endothelial cells, BMSCs may not have provided the optimal growth factors for network development or may even sequester them from cocultures.

Endothelial cells embedded within ECM proliferate and arrange into tubular networks. This is due to availability and diffusion of oxygen and nutrients and also the establishment of microenvironmental gradients [87]. We observed extensive cell proliferation in the vicinity of the aortic tissue, resulting in large cell clusters (Fig. 2a). BMSCs may secrete factors that induce endothelial cell proliferation, thus interfering with endothelial network development. A potential regenerative cell type that indirectly contributes to vascularization should demonstrate beneficial paracrine activity that can fulfill the growth factor demand as well as provide physical support to endothelial cells to sustain endothelial network development. Our results demonstrate the supportive nature of FTM HUCPVCs, contributing to overall network development and stability. We are currently investigating changes in gene expression of critical angiogenic factors following coculture with endothelial cells and also whether the supportive properties of FTM HUCPVCs translate into the promotion of mature and functional vasculature in animal injury models.

One of the key advantages of using the aortic ring assay is the ability to address multiple research questions. To critically analyze the importance of paracrine properties of MSCs in addition to physical cell-to-cell interactions, this assay can also be set up in a transwell system. Thus, the developing endothelial networks and MSCs can exchange secreted paracrine factors while being separated physically. Assay media from cocultures can be analyzed for candidate angiogenic factors using commercially available proteome profilers. Further analysis to determine the fate of multipotent candidate cell types could also be conducted by disrupting cocultures at the endpoint of the assay to sort out human cells from cocultures. Costaining cells with a human cell surface marker (TRA-1-85) and markers of interests can indicate whether candidate cell types have altered expression of multipotency and mesenchymal markers such as CD146 and/or upregulated expression of endothelial markers like CD31 (Additional file 1: Figure S1).

Besides its multiple advantages, there are notable limitations of the described assay. Users need to account for the lag period between embedding of the ex vivo aortic tissue and the initial network development that marks the time of cell administration. Quantification of endothelial network properties can be time consuming but 
can be resolved by assigning hallmark parameters, including radial growth, tube length and network mesh dimensions. Network analysis applications (such as ImageJ) can significantly decrease the time required for consistent and reliable quantification. Variability between each assay can occur as a result of slight inconsistencies in animal tissue source and handling by the operator. We found that this challenge can be efficiently overcome and quantification becomes statistically reliable by setting up triplicates for each treatment group. Lastly, it is difficult to extract and sort cells of human and rat origin from the embedding Matrige ${ }^{\mathrm{Tm}}$ substrate for post-assay analysis. However, specific materials including the Matrigel ${ }^{\text {Th }}$ specific enzyme dispase and cell recovery solution can be applied to recover cells for immunophenotypical or genetic analysis (Table 3).

Cell products prepared for in vivo applications are tested routinely for identity and purity prior to longterm storage. However, high viability and purity may not always translate into greatest functionality $[88,89]$. Storing allogeneic cell lines without prescreening for functionality is problematic. Therefore, robust potency assays are required. One of the limitations for cell therapy is donorbased variability. In our laboratory, FTM HUCPVCs from umbilical cords are isolated at 8-10 weeks of gestation. Because interpatient variability can impact the regenerative potential of cell lines, established cell lines are selected for in vivo applications based on their expansion properties (culturing efficacy) and immunophenotyping results. We also employ various functional in vitro assays, including a transbasal membrane invasion and lymphocyte activation assays, to determine optimal cell lines as well as optimal culture conditions for the expansion of FTM HUCPVCs. In order to assess potential functional differences between cell lines, we tested two different FTM HUCPVCs lines and compared their angiogenic potential to BMSCs, a cell type currently under investigation in numerous clinical trials [90], using this modified aortic ring assay. Overall, this new application revealed greater differences in angiogenic potential between cell types from different origin and was sensitive enough to point out small differences between cell lines of the same tissue origin. Therefore, we present this novel application of the aortic ring assay to not only assess the angiogenic properties of candidate cell types for tissue regeneration, but also to identify the most suitable donor-derived cell lines to bank for future use in cell therapy.

For the present study, we selected and compared two human MSC types from different tissue origins. Both cell types were implemented previously to possess proangiogenic properties and their candidacy for regenerative medicinal applications is heavily based on this attribute. The differences observed between commercially available BMSCs (Lonza) expanded in animal serum (FBS)containing conditions and FTM HUCPVCs expanded in clinically compliant xeno-free media (StemPro) can occur for various reasons. Our aim was to demonstrate that this modified version of the aortic ring assay is robust and sensitive enough to display significant differences in cellular behavior, acknowledging that such differences are inevitably a combination of multiple endogenous and induced characteristics, including the effect of culture conditions. Our laboratory has also investigated the angiogenic properties of FTM HUCPVCs

Table 3 Aortic ring assay

\begin{tabular}{|c|c|}
\hline Advantages & Limitations \\
\hline $\begin{array}{l}\text { - Cost-effective because the aorta is waste tissue from endpoint } \\
\text { animal studies } \\
\text { - From one aorta, a high yield of replicates can be obtained } \\
\text { (approximately } 20 \text { rings per adult animal) } \\
\text { - Rapid set up including aorta isolation and embedding } \\
\text { - Evaluates key steps of angiogenesis including matrix degradation, } \\
\text { cell migration, proliferation and morphogenesis into tubular } \\
\text { endothelial network } \\
\text { - In addition to endothelial cells, includes cell types important for } \\
\text { angiogenesis such as resident pericytes and fibroblasts } \\
\text { - Endothelial cells have not been preselected by passaging and } \\
\text { thus are in a quiescent state at starting point of the assay, } \\
\text { reflecting in vivo conditions } \\
\text { - Quiescent endothelial cells respond by proliferating and } \\
\text { differentiating into tubular networks } \\
\text { - Evaluates properties of cocultured candidate cell types including } \\
\text { the ability to respond to signals of aortic tissue, induce migration, } \\
\text { ECM processing and homing to endothelial networks } \\
\text { - Cell-to-cell connections can be observed using fluorescence } \\
\text { microscopy } \\
\text { - Net effects on angiogenesis can be quantified using image } \\
\text { analysis software to assess various network properties } \\
\text { (network radial growth, loops, branches and nodes) }\end{array}$ & $\begin{array}{l}\text { - Vessel outgrowths occur from a major vessel while in vivo } \\
\text { angiogenesis occurs typically from micro vessels } \\
\text { - Takes } 3-5 \text { days for initial endothelial network to develop } \\
\text { - Variability in angiogenic response can also occur between } \\
\text { animal's due to strain, age and gender } \\
\text { - Lack of blood flow (limitation shared with other in vitro and } \\
\text { ex vivo angiogenesis assays) } \\
\text { - Angiogenic vessel growth is in three dimensions, rendering } \\
\text { imaging and quantification difficult } \\
\text { - Outgrowth vessels regress over time (2 weeks), thereby limiting } \\
\text { long-term analysis }\end{array}$ \\
\hline
\end{tabular}


and BMSCs in other, technically less convenient angiogenic assays often involving live animals. Although the results were similar, we aimed to present the possibilities of the approach that we found to offer the most feasible and reliable application we have come across to date. We propose that the aortic ring assay can be developed as a valuable, quantitative prescreening tool for candidate cell lines for regenerative therapy.

\section{Conclusions}

The presented standardized, direct coculture aortic ring assay is capable of elaborating on the differences in angiogenic potential of mesenchymal stem cells in a multiplex, quantitative manner. The functional comparison of young, extraembryonic human MSCs (FTM HUCPVCs) and adult tissue-originated MSCs (BMSCs) clearly demonstrated both the robustness of this novel in vitro analytical approach and the significant merits of using FTM HUCPVCs for in vivo regenerative applications.

\section{Additional file}

Additional file 1: Figure S1. Showing cellular fractions of aortic ring cultures isolated and processed for flow cytometry analysis. Fluorophoreconjugated antibody against human specific cell surface marker (TRA-1-85(APC)) was applied in combination with MSC/pericyte marker (CD146(FITC), A) or endothelial marker (CD31(FITC), B) specific antibodies. Cell population positive for TRA-1-85 (y axis) tested positive for MSC/pericyte marker (CD146 (A, Q6)) and slight positivity for endothelial marker (CD31 (B, Q1)). This suggests that FTM HUCPVCs maintained their perivascular cell properties in aortic ring cocultures and did not develop an endothelial phenotype. Quadrants defined using isotype controls matching applied primary antibodies. (PDF $91 \mathrm{~kb}$ )

\section{Abbreviations}

BMSC: Bone marrow stromal cell; CTG: Cell tracker green; EBM: Endothelial basal media; ECM: Extracellular matrix; EGM: Endothelial growth media; EPC: Endothelial progenitor cell; FGF: Fibroblast growth factor; FTM: First trimester (of gestation); HUC: Human umbilical cord; HUCPVC: Human umbilical cord perivascular cell; MEM: Minimum essential media; MSC: Mesenchymal stromal cell; NG2: Neural/glial antigen 2; PDGF: Platelet-derived growth factor; PDGFR: PDGF receptor; VCAM-1: Vascular cell adhesion molecule-1; VEGF: Vascular endothelial growth factor

\section{Acknowledgements}

The authors thank the following staff members and research personnel: Tanya Barretto, Tharsan Velauthapillai and Sarah Laronde.

\section{Funding}

This work was supported by CReATe Program Inc., and in part by Graduate Stimulus Award by the University of Toronto.

\section{Supporting data}

Supporting data are available from the corresponding author upon request.

\section{Authors' contributions}

FI was responsible for experimental work, data analysis and manuscript preparation. PS was responsible for concept design, data analysis and manuscript preparation. ML was responsible for experimental assistance and data collection. AG-F was responsible for scientific advising. CLL was responsible for scientific supervision and manuscript preparation. All authors read and approved the final manuscript.

\section{Ethics approval}

All studies involving animals were conducted and reported according to ARRIVE guidelines. All studies were performed with institutional research ethics board approval (REB number 4276). All animal procedures were approved by the Animal Care Committee of the University Health Network (Toronto, Canada, \#3220.5), and all animals received humane care in compliance with the Guide for the Care and Use of Laboratory Animals, 8th edition (National institutes of Health 2011).

\section{Consent for publication}

All authors have consented to publication of the present manuscript

\section{Competing interests}

CLL has filed patent applications in Canada, the USA and Australia for this invention entitled "Method of Isolation and Use of Cells Derived from First Trimester Umbilical Cord Tissue". The applications are currently pending and awaiting examination in Canada and the USA but have received approval in Australia. The remaining authors declare that they have no competing interests.

\section{Publisher's Note}

Springer Nature remains neutral with regard to jurisdictional claims in published maps and institutional affiliations.

\section{Author details}

${ }^{1}$ The Create Fertility Centre, 790 Bay Street, Suite 412, Toronto, Ontario M5G $1 \mathrm{~N} 8$, Canada. ${ }^{2}$ Department of Obstetrics and Gynecology, University of Toronto, 123 Edward Street, Suite 1200, Toronto, Ontario M5G 1E2, Canada. ${ }^{3}$ Department of Physiology, University of Toronto, 1 King's College Circle, Room 3127, Toronto, Ontario M5S 1A8, Canada. ${ }^{4}$ Institute of Medical Sciences, University of Toronto, 1 King's College Circle, Room 2374, Toronto, Ontario M5S 1A8, Canada.

Received: 11 April 2017 Revised: 7 July 2017

Accepted: 12 July 2017 Published online: 14 August 2017

\section{References}

1. Carmeliet P. Angiogenesis in health and disease. Nat Med. 2003:9:653-60.

2. Auerbach $R$, Akhtar N, Lewis RL, Shinners BL. Angiogenesis assays: problems and pitfalls. Cancer Metastasis Rev. 2000;19:167-72.

3. Madeddu P. Therapeutic angiogenesis and vasculogenesis for tissue regeneration. Exp Physiol. 2005;90:315-26.

4. Potente $\mathrm{M}, \mathrm{Gerhardt} \mathrm{H}$, Carmeliet P. Basic and therapeutic aspects of angiogenesis. Cell. 2011;146:873-87.

5. Khan TA, Sellke FW, Laham RJ. Gene therapy progress and prospects: therapeutic angiogenesis for limb and myocardial ischemia. Gene Ther. 2003:10:285-91.

6. Gupta R, Tongers J, Losordo DW. Human studies of angiogenic gene therapy. Circ Res. 2009;105:724-36.

7. Chu H, Wang Y. Therapeutic angiogenesis: controlled delivery of angiogenic factors. Ther Deliv. 2012:3:693-714.

8. Pacilli A, Faggioli G, Stella A, Pasquinelli G. An update on therapeutic angiogenesis for peripheral vascular disease. Ann Vasc Surg. 2010;24:258-68.

9. Deveza L, Choi J, Yang F. Therapeutic angiogenesis for treating cardiovascular diseases. Theranostics. 2012;2:801-14.

10. Cao Y. Therapeutic angiogenesis for ischemic disorders: what is missing for clinical benefits? Discov Med. 2010;9:179-84.

11. Said SS, Pickering JG, Mequanint K. Advances in growth factor delivery for therapeutic angiogenesis. J Vasc Res. 2013;50:35-51.

12. Leeper NJ, Hunter AL, Cooke JP. Stem cell therapy for vascular regeneration: adult, embryonic, and induced pluripotent stem cells. Circulation. 2010;122:517-26.

13. Sieveking DP, Ng MK. Cell therapies for therapeutic angiogenesis: back to the bench. Vasc Med. 2009;14:153-66.

14. Rafii S, Lyden D. Therapeutic stem and progenitor cell transplantation for organ vascularization and regeneration. Nat Med. 2003;9:702-12.

15. Urbich C, Dimmeler S. Endothelial progenitor cells: characterization and role in vascular biology. Circ Res. 2004;95:343-53.

16. Wei X, Yang X, Han ZP, Qu FF, Shao L, Shi YF. Mesenchymal stem cells: a new trend for cell therapy. Acta Pharmacol Sin. 2013;34:747-54.

17. Huang NF, Li S. Mesenchymal stem cells for vascular regeneration. Regen Med. 2008;3:877-92. 
18. Staton CA, Reed MW, Brown NJ. A critical analysis of current in vitro and in vivo angiogenesis assays. Int J Exp Pathol. 2009;90:195-221.

19. Gomez D, Reich NC. Stimulation of primary human endothelial cell proliferation by IFN. J Immunol. 2003;170:5373-81.

20. Yu CH, Wu J, Su YF, Ho PY, Liang YC, Sheu MT, et al. Anti-proliferation effect of 3-amino-2-imino-3,4-dihydro-2H-1,3-benzothiazin-4-one (BJ-601) on human vascular endothelial cells: G0/G1 p21-associated cell cycle arrest. Biochem Pharmacol. 2004;67:1907-16.

21. Wong MK, Gotlieb Al. In vitro reendothelialization of a single-cell wound. Role of microfilament bundles in rapid lamellipodia-mediated wound closure. Lab Invest. 1984;51:75-81.

22. Schor AM, Ellis I, Schor SL. Chemotaxis and chemokinesis in 3D macromolecular matrices: relevance to angiogenesis. Methods Mol Med. 2001;46:163-83.

23. Albini A, Benelli R, Noonan DM, Brigati C. The "chemoinvasion assay": a tool to study tumor and endothelial cell invasion of basement membranes. Int J Dev Biol. 2004;48:563-71.

24. Lawley TJ, Kubota Y. Induction of morphologic differentiation of endothelial cells in culture. J Invest Dermatol. 1989:93:59S-61S.

25. Kanzawa S, Endo H, Shioya N. Improved in vitro angiogenesis model by collagen density reduction and the use of type III collagen. Ann Plast Surg. 1993;30:244-51.

26. Auerbach R, Lewis R, Shinners B, Kubai L, Akhtar N. Angiogenesis assays: a critical overview. Clin Chem. 2003;49:32-40.

27. Ribatti D, Urbinati C, Nico B, Rusnati M, Roncali L, Presta M. Endogenous basic fibroblast growth factor is implicated in the vascularization of the chick embryo chorioallantoic membrane. Dev Biol. 1995;170:39-49.

28. Ejaz S, Seok KB, Woong LC. A novel image probing system for precise quantification of angiogenesis. Tumori. 2004;90:611-7.

29. Passaniti A, Taylor RM, Pili R, Guo Y, Long PV, Haney JA, et al. A simple, quantitative method for assessing angiogenesis and antiangiogenic agents using reconstituted basement membrane, heparin, and fibroblast growth factor. Lab Invest. 1992;67:519-28

30. Baker JH, Huxham LA, Kyle AH, Lam KK, Minchinton Al. Vascular-specific quantification in an in vivo Matrigel chamber angiogenesis assay. Microvasc Res. 2006;71:69-75.

31. Salvatore JE, Gilmer Jr WS, Kashgarian M, Barbee WR. An experimental study of the influence of pore size of implanted polyurethane sponges upon subsequent tissue formation. Surg Gynecol Obstet. $1961 ; 112: 463-8$

32. Dellian M, Witwer BP, Salehi HA, Yuan F, Jain RK. Quantitation and physiological characterization of angiogenic vessels in mice: effect of basic fibroblast growth factor, vascular endothelial growth factor/vascular permeability factor, and host microenvironment. Am J Pathol. 1996;149:59-71

33. Gimbrone Jr MA, Cotran RS, Folkman J. Human vascular endothelial cells in culture. Growth and DNA synthesis. J Cell Biol. 1974;60:673-84.

34. Muthukkaruppan V, Auerbach R. Angiogenesis in the mouse cornea. Science. 1979:205:1416-8.

35. Selye $\mathrm{H}$. On the mechanism through which hydrocortisone affects the resistance of tissues to injury; an experimental study with the granuloma pouch technique. J Am Med Assoc. 1953;152:1207-13.

36. Oikawa T, Sasaki M, Inose M, Shimamura M, Kuboki H, Hirano S, et al. Effects of cytogenin, a novel microbial product, on embryonic and tumor cell-induced angiogenic responses in vivo. Anticancer Res. 1997;17:1881-6.

37. Rubinstein AL. Zebrafish: from disease modeling to drug discovery. Curr Opin Drug Discov Dev. 2003;6:218-23.

38. Isogai $\mathrm{S}$, Horiguchi $\mathrm{M}$, Weinstein $\mathrm{BM}$. The vascular anatomy of the developing zebrafish: an atlas of embryonic and early larval development. Dev Biol. 2001;230:278-301.

39. Goodwin AM. In vitro assays of angiogenesis for assessment of angiogenic and anti-angiogenic agents. Microvasc Res. 2007;74:172-83.

40. Baker M, Robinson SD, Lechertier T, Barber PR, Tavora B, D'Amico G, et al. Use of the mouse aortic ring assay to study angiogenesis. Nat Protoc. 2012;7:89-104.

41. Nicosia RF, Ottinetti A. Growth of microvessels in serum-free matrix culture of rat aorta. A quantitative assay of angiogenesis in vitro. Lab Invest. 1990;63:115-22.

42. Bellacen K, Lewis EC. Aortic ring assay. J Vis Exp. 2009;33:e1564.

43. Nicosia RF. The aortic ring model of angiogenesis: a quarter century of search and discovery. J Cell Mol Med. 2009;13:4113-36.
44. De Rossi G, Scotland R, Whiteford J. Critical factors in measuring angiogenesis using the aortic ring model. J Genet Syndr Gene Ther. 2013; 4(5):1000147.

45. Guo J, Zhang Y, Mihic A, Li SH, Sun Z, Shao Z, et al. A secreted protein (Canopy 2, CNPY2) enhances angiogenesis and promotes smooth muscle cell migration and proliferation. Cardiovasc Res. 2015;105:383-93.

46. Yakkundi A, Bennett R, Hernandez-Negrete I, Delalande JM, Hanna M, Lyubomska $\mathrm{O}$, et al. FKBPL is a critical antiangiogenic regulator of developmental and pathological angiogenesis. Arterioscler Thromb Vasc Biol. 2015;35:845-54.

47. Wittig C, Scheuer C, Parakenings J, Menger MD, Laschke MW. Geraniol suppresses angiogenesis by downregulating vascular endothelial growth factor (VEGF)NEGFR-2 signaling. PLoS One. 2015;10, e0131946.

48. Stati T, Musumeci M, Maccari S, Massimi A, Corritore E, Strimpakos G, et al beta-Blockers promote angiogenesis in the mouse aortic ring assay. J Cardiovasc Pharmacol. 2014;64:21-7.

49. Masson W, Devy L, Grignet-Debrus C, Bernt S, Bajou K, Blacher S, et al. Mouse aortic ring assay: a new approach of the molecular genetics of angiogenesis. Biol Proced Online. 2002;4:24-31.

50. Piqueras $L$, Reynolds AR, Hodivala-Dilke KM, Alfranca A, Redondo JM, Hatae T, et al. Activation of PPARbeta/delta induces endothelial cell proliferation and angiogenesis. Arterioscler Thromb Vasc Biol. 2007;27:63-9.

51. Kolf CM, Cho E, Tuan RS. Mesenchymal stromal cells. Biology of adult mesenchymal stem cells: regulation of niche, self-renewal and differentiation. Arthritis Res Ther. 2007;9:204.

52. Keating A. Mesenchymal stromal cells: new directions. Cell Stem Cell. 2012;10:709-16.

53. Caplan Al. Adult mesenchymal stem cells for tissue engineering versus regenerative medicine. J Cell Physiol. 2007;213:341-7.

54. Phinney DG, Prockop DJ. Concise review: mesenchymal stem/multipotent stromal cells: the state of transdifferentiation and modes of tissue repair_current views. Stem Cells. 2007;25:2896-902.

55. Bianco P, Riminucci M, Gronthos S, Robey PG. Bone marrow stromal stem cells: nature, biology, and potential applications. Stem Cells. 2001;19:180-92.

56. Watt SM, Gullo F, van der Garde M, Markeson D, Camicia R, Khoo CP, et al. The angiogenic properties of mesenchymal stem/stromal cells and their therapeutic potential. Br Med Bull. 2013;108:25-53.

57. Gnecchi M, Zhang Z, Ni A, Dzau VJ. Paracrine mechanisms in adult stem cell signaling and therapy. Circ Res. 2008;103:1204-19.

58. Zhang $H$, Fazel $S$, Tian H, Mickle DA, Weisel RD, Fujii T, et al. Increasing donor age adversely impacts beneficial effects of bone marrow but not smooth muscle myocardial cell therapy. Am J Physiol Heart Circ Physiol. 2005:289:H2089-96.

59. Rasmusson I, Ringden O, Sundberg B, Le Blanc K. Mesenchymal stem cells inhibit the formation of cytotoxic T lymphocytes, but not activated cytotoxic $T$ lymphocytes or natural killer cells. Transplantation. 2003;76:1208-13.

60. Sethe S, Scutt A, Stolzing A. Aging of mesenchymal stem cells. Ageing Res Rev. 2006;5:91-116.

61. Fan M, Chen W, Liu W, Du GQ, Jiang SL, Tian WC, et al. The effect of age on the efficacy of human mesenchymal stem cell transplantation after a myocardial infarction. Rejuvenation Res. 2010;13:429-38.

62. Liu L, Rando TA. Manifestations and mechanisms of stem cell aging I Cell Biol. 2011:193:257-66.

63. Stolzing A, Jones E, McGonagle D, Scutt A. Age-related changes in human bone marrow-derived mesenchymal stem cells: consequences for cell therapies. Mech Ageing Dev. 2008;129:163-73.

64. Sarugaser R, Ennis J, Stanford WL, Davies JE. Isolation, propagation, and characterization of human umbilical cord perivascular cells (HUCPVCs). Methods Mol Biol. 2009:482:269-79.

65. Sarugaser R, Lickorish D, Baksh D, Hosseini MM, Davies JE. Human umbilical cord perivascular (HUCPV) cells: a source of mesenchymal progenitors. Stem Cells. 2005:23:220-9.

66. Hong SH, Maghen L, Kenigsberg S, Teichert AM, Rammeloo AW, Shlush E, et al. Ontogeny of human umbilical cord perivascular cells: molecular and fate potential changes during gestation. Stem Cells Dev. 2013;22:2425-39.

67. Wang HS, Hung SC, Peng ST, Huang CC, Wei HM, Guo YJ, et al. Mesenchymal stem cells in the Wharton's jelly of the human umbilical cord. Stem Cells. 2004;22:1330-7.

68. Szaraz P, Lucato A, Li SH, Wu J, Gauthier-Fisher A, Li R-K, et al. Local injection of first trimester human umbilical cord perivascular cells (FTM-HUCPVCS) after myocardial infarction increases extracellular matrix processing activity, 
vascular density and blood vessel size within the infarct scar. Circulation. 2015;132:A19359-A.

69. Hughes CS, Postovit LM, Lajoie GA. Matrigel: a complex protein mixture required for optimal growth of cell culture. Proteomics. 2010:10:1886-90.

70. Schneider CA, Rasband WS, Eliceiri KW. NIH Image to ImageJ: 25 years of image analysis. Nat Methods. 2012;9:671-5.

71. Cuenod CA, Balvay D. Perfusion and vascular permeability: basic concepts and measurement in DCE-CT and DCE-MRI. Diagn Interv Imaging. 2013;94:1187-204.

72. Mingliang R, Bo Z, Zhengguo W. Stem cells for cardiac repair: status, mechanisms, and new strategies. Stem Cells Int. 2011;2011:310928.

73. Lian DYaQ. Optimal cells for cardiac repair and regeneration. Cardiac regeneration and repair: pathology and therapies. Waltham: Woodhead Publishing; 2014.

74. Behfar A, Crespo-Diaz R, Terzic A, Gersh BJ. Cell therapy for cardiac repair-lessons from clinical trials. Nat Rev Cardiol. 2014;11:232-46.

75. Vailhe $B$, Vittet $D$, Feige $J$ J. In vitro models of vasculogenesis and angiogenesis. Lab Invest. 2001;81:439-52.

76. Senger DR, Davis GE. Angiogenesis. Cold Spring Harb Perspect Biol. 2011:3:a005090.

77. Gaengel K, Genove G, Armulik A, Betsholtz C. Endothelial-mural cell signaling in vascular development and angiogenesis. Arterioscler Thromb Vasc Biol. 2009;29:630-8.

78. Armulik A, Abramsson A, Betsholtz C. Endothelial/pericyte interactions. Circ Res. 2005;97:512-23.

79. Yu KR, Yang SR, Jung JW, Kim H, Ko K, Han DW, et al. CD49f enhances multipotency and maintains stemness through the direct regulation of OCT4 and SOX2. Stem Cells. 2012;30:876-87.

80. Yamamoto H, Masters JR, Dasgupta P, Chandra A, Popert R, Freeman A, et al. CD49f is an efficient marker of monolayer- and spheroid colony-forming cells of the benign and malignant human prostate. PLoS One. 2012;7:e46979.

81. Kayisli UA, Korgun ET, Akkoyunlu G, Arici A, Demir R. Expression of integrin alpha5 and integrin beta4 and their extracellular ligands fibronectin and laminin in human decidua during early pregnancy and its sex steroid-mediated regulation. Acta Histochem. 2005:107:173-85.

82. Szaraz P, Librach M, Maghen L, lqbal F, Barretto TA, Kenigsberg S, et al. In vitro differentiation of first trimester human umbilical cord perivascular cells into contracting cardiomyocyte-like cells. Stem Cells Int. 2016;2016:7513252.

83. Bexell D, Gunnarsson S, Tormin A, Darabi A, Gisselsson D, Roybon L, et al. Bone marrow multipotent mesenchymal stroma cells act as pericyte-like migratory vehicles in experimental gliomas. Mol Ther. 2009;17:183-90.

84. Shi S, Gronthos S. Perivascular niche of postnatal mesenchymal stem cells in human bone marrow and dental pulp. J Bone Miner Res. 2003;18:696-704.

85. Jones $\mathrm{E}$, McGonagle D. Human bone marrow mesenchymal stem cells in vivo. Rheumatology (Oxford). 2008:47:126-31.

86. Franco CA, Jones ML, Bernabeu MO, Geudens I, Mathivet T, Rosa A, et al. Dynamic endothelial cell rearrangements drive developmental vessel regression. PLoS Biol. 2015;13, e1002125.

87. Helmlinger G, Endo M, Ferrara N, Hlatky L, Jain RK. Formation of endothelial cell networks. Nature. 2000;405:139-41.

88. Sensebe L, Bourin P, Tarte K. Good manufacturing practices production of mesenchymal stem/stromal cells. Hum Gene Ther. 2011;22:19-26.

89. Sharma RR, Pollock K, Hubel A, McKenna D. Mesenchymal stem or stromal cells: a review of clinical applications and manufacturing practices. Transfusion. 2014:54:1418-37.

90. Trounson A, Thakar RG, Lomax G, Gibbons D. Clinical trials for stem cell therapies. BMC Med. 2011:9:52

\section{Submit your next manuscript to BioMed Central and we will help you at every step:}

- We accept pre-submission inquiries

- Our selector tool helps you to find the most relevant journal

- We provide round the clock customer support

- Convenient online submission

- Thorough peer review

- Inclusion in PubMed and all major indexing services

- Maximum visibility for your research

Submit your manuscript at www.biomedcentral.com/submit
Biomed Central 